\title{
sciendo
}

\section{EFFECT OF DIFFERENT LEVELS OF COPPER NANOPARTICLES AND COPPER SULFATE ON MORPHOMETRIC INDICES, ANTIOXIDANT STATUS AND MINERAL DIGESTIBILITY IN THE SMALL INTESTINE OF TURKEYS*}

\author{
Jan Jankowski ${ }^{1}$, Kamil Otowski ${ }^{1}$, Krzysztof Kozłowski ${ }^{1}$, Piotr Pietrzak ${ }^{2}$, Karolina Ferenc ${ }^{2}$, \\ Katarzyna Ognik ${ }^{3}$, Jerzy Juśkiewicz ${ }^{4}$, Ewa Sawosz ${ }^{5}$, Zenon Zduńczyk ${ }^{4 \bullet}$
}

\author{
${ }^{1}$ Department of Poultry Science, Faculty of Animal Bioengineering, University of Warmia and Mazury \\ in Olsztyn, Oczapowskiego 5, 10-719 Olsztyn, Poland \\ ${ }^{2}$ Department of Large Animal Diseases with Clinic, Warsaw University of Life Sciences, \\ Nowoursynowska 159, 02-776 Warsaw, Poland \\ ${ }^{3}$ Department of Biochemistry and Toxicology, Faculty of Biology, Animal Sciences and Bioeconomy, \\ University of Life Sciences in Lublin, Akademicka 13, 20-950 Lublin, Poland \\ ${ }^{4}$ Institute of Animal Reproduction and Food Research, Polish Academy of Sciences, Tuwima 10, \\ 10-748 Olsztyn, Poland \\ ${ }^{5}$ Department of Animal Nutrition and Biotechnology, Warsaw University of Life Sciences, \\ Ciszewskiego 8, 02-786 Warsaw, Poland \\ •Corresponding author: z.zdunczyk@pan.olsztyn.pl
}

\begin{abstract}
It was hypothesized that dietary copper $(\mathrm{Cu})$ nanoparticles, as a substitute for the commonly used copper sulfate, could contribute to lowering the dietary inclusion levels of $\mathrm{Cu}$ without compromising growth performance or reducing $\mathrm{Cu}$ digestibility and utilization in turkeys. An experiment was carried out on 648 one-day-old Hybrid Converter turkeys divided into 6 groups with 6 replicates per group in a two-factorial design with 3 dietary inclusion levels of $\mathrm{Cu}(20,10$ and $2 \mathrm{mg} \mathrm{kg}^{-1}$ ) and 2 dietary sources of $\mathrm{Cu}$, copper sulfate and $\mathrm{Cu}$ nanoparticles (Cu-SUL and $\mathrm{Cu}-\mathrm{NPs}$, respectively). The apparent digestibility coefficients of minerals were determined after 6 weeks, and tissue samples were collected after 14 weeks of experimental feeding. A decrease in the dietary inclusion levels of $\mathrm{Cu}$ from 20 to 10 and $2 \mathrm{mg} \mathrm{kg}^{-1}$ did not reduce the body weights of turkeys at 42 and 98 days of age. In comparison with the remaining treatments, the lowest dietary inclusion level of $\mathrm{Cu}$ significantly decreased MDA concentrations in small intestinal tissue $(\mathrm{P}=0.002)$ and in the bursa of Fabricius $(\mathrm{P}=\mathbf{0 . 0 0 1})$. The replacement of $\mathrm{Cu}-\mathrm{SUL}$ with $\mathrm{Cu}-\mathrm{NPs}$ differentially modulated the redox status of selected tissues, i.e., enhanced SOD activity in small intestinal tissue $(\mathrm{P}=0.001)$ and decreased total glutathione levels in the bursa of Fabricius $(P=0.005)$. In general, neither the different levels nor sources of additional dietary $\mathrm{Cu}$ (main factors) exerted negative effects on the histological structure of the duodenum and jejunum in turkeys. The intestinal digestibility of $\mathrm{Cu}$
\end{abstract}

*This work was supported by the National Centre for Research and Development: Biostrateg program "GUTFEED - innovative nutrition in sustainable poultry production"; No. 267659/7/NCBR/2015, Poland. 
increased with decreasing dietary $\mathrm{Cu}$ levels, and as a consequence, the highest apparent digestibility coefficient of $\mathrm{Cu}$ (and zinc) was noted in turkeys fed diets with the addition of $2 \mathrm{mg} \mathrm{kg}^{-1} \mathrm{Cu}-$ NPs. Therefore, the environmental burden of excreted $\mathrm{Cu}$ was substantially reduced along with decreasing dietary $\mathrm{Cu}$ levels but it did not depend on the $\mathrm{Cu}$ source.

Key words: copper, nanoparticles, small intestine, redox status, turkeys

In modern poultry farming, diets are routinely supplemented with copper $(\mathrm{Cu})$ compounds to meet the requirements of intensively reared birds and improve their health. The results of many experiments show that $\mathrm{Cu}$ added to poultry diets at increased doses (above $150 \mathrm{mg} \mathrm{kg}^{-1}$ ) stimulates growth and laying performance (Samanta et al., 2011; Lim and Paik, 2006; Jegede et al., 2012). One of the negative consequences of high dietary inclusion levels of $\mathrm{Cu}$, particularly in the form of sulfate, is increased $\mathrm{Cu}$ excretion, which leads to environmental mineral pollution (Bao et al., 2007). To address this problem, organic sources of dietary $\mathrm{Cu}$ should be used, such as chelates combined with amino acids, which are characterized by higher bioavailability and can help reduce the excretion of environmental contaminants (Karimi et al., 2011). Nanoparticles, including $\mathrm{Cu}$ nanoparticles (Cu-NPs), can also be used as feed additives to improve digestion and absorption in livestock (Bunglavan et al., 2014; Gangadoo et al., 2016; Hill and Li, 2017; Sawosz et al., 2018; Scott et al., 2018; Anwar et al., 2019). An experiment performed on piglets revealed that dietary supplementation with $50 \mathrm{Cu}$ nanoparticles improved growth performance, increased availability and reduced faecal $\mathrm{Cu}$ excretion compared with those of the $\mathrm{Cu}-\mathrm{SUL}$ group (Gonzales-Eguia et al., 2009). A recent study on model rats showed that the use of a reduced dose of $\mathrm{Cu}$ vs. the recommended dose positively affected the redox status of the body, and the use of copper nanoparticles vs. common $\mathrm{CuCO}_{3}$ beneficially protected proteins and DNA against oxidation and nitration processes (Jóźwik et al., 2018; Ognik et al., 2019 a, b; Otowski et al., 2019).

Intestinal mucus and the intestinal walls are the first barriers through which ingested NPs, including Cu-NPs, must pass (Crater and Carrier, 2010). It has been reported that mucin interaction with adhesive NPs can disrupt the "bottle-brush" architecture of mucus (McGill and Smyth, 2010), and metal NPs can be trapped in intestinal mucus by adhesive interactions (Jachak et al., 2012). In addition, different doses and/or $\mathrm{Cu}$ activity can induce changes in the microbiota population and indirectly affect mucosal histology (Johnson et al., 1985; Awad et al., 2009). Studies on polystyrene nanoparticles show that small particles are capable of being taken up by the villus epithelium and may enter the bloodstream directly or via the lymph system, where they are then predominantly scavenged by the liver and spleen (Jani et al., 1990; Hillery et al., 1994). Majewski et al. (2017) showed a strong relationship between dietary copper nanoparticles and $\mathrm{CuCO}_{3}$ salt in the tensile strength of the thoracic aorta, and those effects were attributed to the nanoparticles rather than the copper itself.

Due to their small size, ranging between 1 and $100 \mathrm{~nm}\left(10^{-9}-10^{-7} \mathrm{~m}\right)$, nanoparticles are characterized by a relatively large surface area (Chen et al., 2006; Albanese 
et al., 2012; Scott et al., 2018). It was found that the relatively large surface area of $\mathrm{Cu}-N P s(25 \mathrm{~nm})$ contributed to their higher toxicity compared with that of microcopper particles $(17 \mu \mathrm{m})$ and cupric ions $\left(\mathrm{CuC}_{12} \cdot 2 \mathrm{H}_{2} \mathrm{O}\right)$ (Chen et al., 2006). Toxicological and feeding tests with high $\mathrm{Cu}-\mathrm{NP}$ doses have revealed the resulting dysfunction of many organs and tissues in mice and rats (Chen et al., 2006; Cholewińska et al., 2018 b). In feeding trials with low levels of $\mathrm{Cu}-\mathrm{NP}, \mathrm{Cu}$ exerted no adverse effect on the experimental animals and even improved the feed efficiency (Gonzales-Eguia et al., 2009; Cholewińska et al., 2018 a). This is an important consideration since, according to the current EU recommendations, the $\mathrm{Cu}$ content of poultry diets should not exceed $25 \mathrm{mg} \mathrm{kg}^{-1}$ feed (EFSA, 2016). Thus, feed additives should contain highly bioavailable $\mathrm{Cu}$, and research should be continued to evaluate the physiological effects of reducing the dietary inclusion levels of $\mathrm{Cu}$ in intensive poultry farming (Ognik et al., 2018).

The aim of this study was to verify the following hypothesis: $\mathrm{Cu}$ nanoparticles are characterized by higher bioavailability and biological reactivity in vivo than $\mathrm{Cu}$ sulfate; therefore, dietary inclusion levels of $\mathrm{Cu}$ can be lowered without compromising the gastrointestinal function and growth rate of turkeys. As a result, the amount of $\mathrm{Cu}$ in animal nutrition and $\mathrm{Cu}$ release into the environment can be reduced.

\section{Material and methods}

A total of 648 one-day-old Hybrid Converter female turkeys purchased from the Grelavi Hatchery in Kętrzyn (Poland) were randomly placed in 36 pens, with 18 birds per pen, with a surface area of $3.7 \mathrm{~m}^{2}$. The pens were bedded with wood shavings. The stock density was $4.86 \mathrm{birds} / \mathrm{m}^{2}$ until week 6 and $3.2 \mathrm{birds} / \mathrm{m}^{2}$ from week 6 until the end of the experiment. Turkeys had free access to feed and water, and age-appropriate management conditions were consistent with the breeding company's recommendations (Hybrid Turkeys, 2014).

Turkeys were divided into 6 groups with 6 replicates per group in a two-factorial design with 3 dietary inclusion levels of $\mathrm{Cu}\left(20,10\right.$ and $\left.2 \mathrm{mg} \mathrm{kg}^{-1}\right)$ and 2 dietary sources of $\mathrm{Cu}$ : copper sulfate and $\mathrm{Cu}$ nanoparticles (Cu-SUL and $\mathrm{Cu}-\mathrm{NPs}$ ). Copper nanoparticles ( $25 \mathrm{~nm}$ in size) in the form of powder ( $99.8 \%$ purity), purchased from Sky Spring Nanomaterials Inc. (USA), were added to a vitamin-mineral premix using a starch carrier. The experiment was approved by the local Ethical Committee for Experiments on Animals in Olsztyn (permission no. 30/2015), and all animals were treated according to EU Directive 2010/63/EU.

The composition of the basal diets, which were supplemented with different doses of $\mathrm{Cu}$, is given in Table 1. Diets were prepared at "Agrocentrum" Feed Mill Ltd. in two stages: (1) basal diets were prepared without the vitamin-mineral premix, and (2) diets for the experimental groups were supplemented with vitamin-mineral premixes containing different levels and sources of $\mathrm{Cu}$, thoroughly mixed, pelleted and crumbled. The birds were weighed at the beginning (day 1) and at 42 and 102 days of age. Feed consumption was monitored on a turkey pen basis. The feed conversion 
ratio (FCR, $\mathrm{kg}$ of feed per $\mathrm{kg}$ of body weight gain) was then calculated. At 102 days of age, 6 birds from each dietary treatment were slaughtered in the experimental slaughterhouse after $8 \mathrm{~h}$ of feed withdrawal. The procedure was approved by the Local Animal Care and Use Committee. The birds were electrically stunned (400 mA, $350 \mathrm{~Hz}$ ), hung on a shackle line and exsanguinated by a unilateral neck cut severing the right carotid artery and jugular vein. After slaughter, the carcasses were scalded, plucked, and eviscerated, and intestinal samples were taken. Three sections were collected for a morphometric analysis of the small intestine, and the bursa of Fabricius and $10 \mathrm{~cm}$ segments of the small intestine (starting from Meckel's diverticulum) were collected to determine oxidative stress indices.

Table 1. Composition and nutritional value of experimental turkey diets ( $\mathrm{g} \mathrm{kg}^{-1}$, as-fed basis)

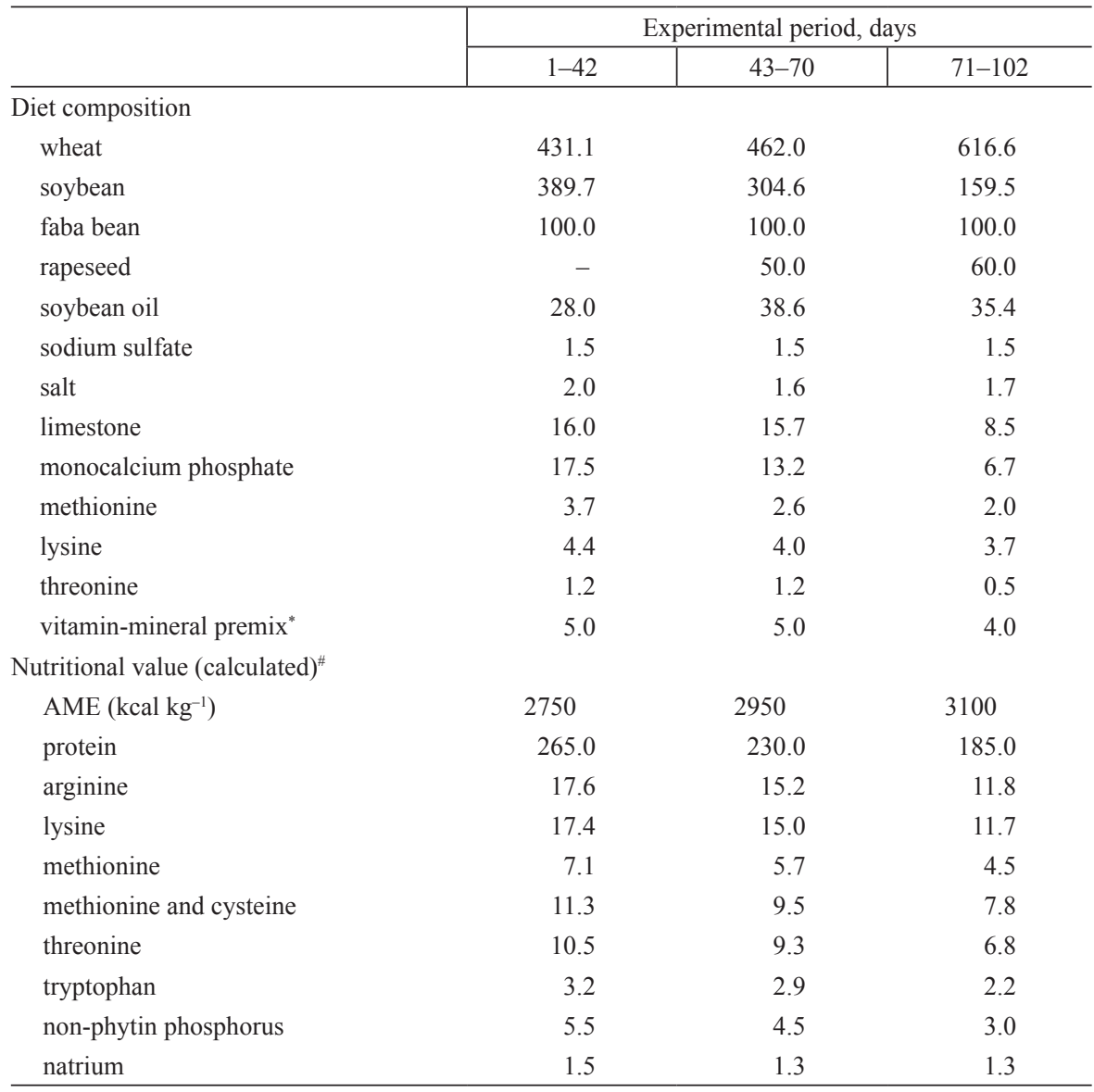

${ }^{*}$ Per kg of diet: vit. A - 24999.75 IU, vit. D - $35000 \mathrm{IU}$, vit. E - $100 \mathrm{IU}$, tocopherol - $91 \mathrm{mg}$, vit. K - $4 \mathrm{mg}$, vit. $\mathrm{B}_{1}-5 \mathrm{mg}$, vit. $\mathrm{B}_{2}-15 \mathrm{mg}$, vit. $\mathrm{B}_{6}-6 \mathrm{mg}$, vit. $\mathrm{B}_{12}-0.04 \mathrm{mg}$, niacin $-100 \mathrm{mg}$, pantothenic acid $-30 \mathrm{mg}$, folic acid $-4 \mathrm{mg}$, choline chloride $-700 \mathrm{mg}$, calcium d-pantothenate $-32.665 \mathrm{mg}$, biotin $-0.35 \mathrm{mg}$, total Se $-0.3 \mathrm{mg}$, total $\mathrm{Fe}-60 \mathrm{mg}$, total $\mathrm{Mn}-100 \mathrm{mg}$, total $\mathrm{Zn}-100 \mathrm{mg}, \mathrm{I}-1.5 \mathrm{mg}, \mathrm{Ca}-1.0435 \mathrm{~g}$.

\#The contents of nutrients and non-nutrients were calculated according to the Polish Feedstuff Analysis Tables (Smulikowska and Rutkowski, 2005). The analytically verified protein content in the diets of subsequent feeding periods was $258.8,225.7$ and $179.1 \mathrm{~g} / \mathrm{kg}$, respectively. 


\section{Laboratory analyses}

As described previously (Ognik and Wertelecki, 2012), the following indicators of redox status were determined in the small intestinal wall and the bursa of Fabricius of the turkeys: activities of superoxide dismutase (SOD) and catalase (CAT) and concentrations of vitamin $\mathrm{C}$, the sum of reduced and oxidized glutathione (GSH + GSSG), hydroperoxides (LOOH) and malondialdehyde (MDA). The activity of CAT was determined according to Aebi (1984), the activity of SOD was determined using Ransod and Ransel diagnostic kits (Randox Laboratories, Crumlin, UK), and the vitamin C concentration was determined according to Omaye et al. (1979). For MDA determination, $1 \mathrm{~g}$ tissue samples were weighed accurately, adding 9 times the volume of PBS (phosphate buffer saline) $(0.01 \mathrm{M}, \mathrm{pH} 7 \sim 7.4)$ at a weight $(\mathrm{g})$ :volume $(\mathrm{ml})$ ratio of 1:9. The samples were homogenized in an ice-water bath and then centrifuged at 10,000 $\mathrm{g}$ for $10 \mathrm{~min}$. The supernatant was stored on ice until MDA determination. For the remaining determinations (SOD, CAT, GSH), the tissues were homogenized in PBS (0.01 M, pH 7.4) on ice at a PBS volume $(\mathrm{ml})$ :tissue weight $(\mathrm{g})$ ratio of 9:1. The tissue homogenate was centrifuged at $1500 \mathrm{~g}$ for 15 minutes, and the supernatant was collected.

To study intestinal morphometry, one square centimetre of whole thickness tissue samples from the duodenum, proximal, middle and distal jejunum was taken. The samples were placed in 4\% buffered formaldehyde (Sigma-Aldrich Co., St. Louis, Missouri, USA) for 5 days and then stored in ethanol. The samples were embedded in paraffin, and serial histological sections ( $5 \mu \mathrm{m}$ thick) were stained with haematoxylin and eosin for histometric analysis under a light microscope. Villus length, crypt depth, and the thickness of the tunica mucosa and tunica muscularis were measured in 5 to 8 slides for each tissue sample with an optical binocular microscope (OLYMPUS BX 61, Warsaw, Poland) coupled to a digital camera and a PC computer equipped with $\mathrm{Cell}^{\wedge} \mathrm{P}$ (OLYMPUS) software. Thirty measurements were performed for each analysed parameter.

To investigate the intestinal digestibility of $\mathrm{Cu}$ and selected mineral elements in the diets prepared for days 1 to 42 , titanium dioxide $\left(\mathrm{TiO}_{2}\right)$ was introduced. On day 42 of the experiment, 6 birds per pen were randomly selected, stunned and sacrificed by cervical dislocation. The ileum was dissected from Meckel's diverticulum to the ileo-ceco-colonic junction, and the digesta was collected from the distal 2/3 for apparent ileal digestibility (AID) determination. Samples of ileal digesta from all birds within each pen were pooled ( 6 pooled samples per treatment) and immediately frozen $\left(-80^{\circ} \mathrm{C}\right)$ until further analysis. The pooled digesta was freeze-dried before chemical analyses. Samples, varying in weight from $25 \mathrm{mg}$ to $500 \mathrm{mg}$, were digested with $4 \mathrm{~mL} \mathrm{H}_{2} \mathrm{SO}_{4}$ (SUPRAPUR, Merck) and $2 \mathrm{~mL} \mathrm{H}_{2} \mathrm{O}_{2}$ (SUPRAPUR, Merck) in closed $50 \mathrm{~mL}$ quartz vessels using the Multiwave ${ }^{\circledR}$ microwave sample preparation system (Anton Paar Graz, Austria). After cooling, $5.0 \mathrm{~mL}$ of an internal standard reagent (Yttrium; $10 \mathrm{mg}$ Y/L) was added and brought up to $1000 \mathrm{~mL}$ with DI water. To avoid acid interference effects, the acid concentration of all solutions was identical to that in the digested samples.

The $\mathrm{Cu}$ content of diet samples and ileal digesta was determined by inductively coupled plasma optical emission spectroscopy (ICP-OES, Varian Inc., Palo Alto, $\mathrm{CA}$, USA). The contents of zinc $(\mathrm{Zn})$, calcium $(\mathrm{Ca})$, phosphorus $(\mathrm{P})$ and iron $(\mathrm{Fe})$ in 
the same samples were determined by flame atomic absorption spectroscopy (FAAS, Varian Inc., Palo Alto, CA, USA). All analyses were performed in triplicate. To analyse the intestinal digestibility of $\mathrm{Cu}$ and of the selected mineral elements in the diets prepared for days 1 to 42, titanium dioxide $\left(\mathrm{TiO}_{2}\right.$; Sigma Aldrich, St. Louis, $\mathrm{MO}$ ) in the amount of $0.5 \%$ was introduced, and, later, it was analysed in both feed and digesta samples by ICP-OES (Varian Inc., Palo Alto, CA, USA). The following formula was used for AID calculations:

AID of nutrient $=\{1-[$ (concentration of marker in feed/concentration of marker in ileum $) \times($ concentration of nutrient in ileum/concentration of nutrient in feed $)]\} \times$ $100 \%$

\section{Statistical analysis}

Two-way ANOVA was performed to determine the effects of the $\mathrm{Cu}$ inclusion level (20, 10 and $\left.2 \mathrm{mg} \mathrm{kg}^{-1}\right)$ and source (Cu-SUL or $\left.\mathrm{Cu}-\mathrm{NP}\right)$ and the interaction between both factors (level $\times$ source; $\mathrm{L} \times \mathrm{S}$ ). The significance of differences between the mean values of the analysed parameters in groups was estimated by Duncan's multiple range test. The data were processed in the Statistica PL 12.0 application.

\section{Results}

\section{Dietary $\mathrm{Cu}$ content and growth performance}

In the first stage of the present experiment (1-42 days), the $\mathrm{Cu}$ content of the experimental diets was close to the expected values (Table 2). Minor differences in the content of $\mathrm{Cu}$ in the subsequent feeding period could have resulted from differences in the accuracy of the analytical technique as well as from changes in the diet composition. The difference between the total $\mathrm{Cu}$ content of the diets and of the supplemental $\mathrm{Cu}$ doses indicates that major feed ingredients provided over $10 \mathrm{mg}$ $\mathrm{kg}^{-1} \mathrm{Cu}$ in total.

Table 2. Analysed mineral composition of experimental turkey diets

\begin{tabular}{|c|c|c|c|}
\hline & \multicolumn{3}{|c|}{ Experimental period, days } \\
\hline & $1-42$ & $43-70$ & $71-102$ \\
\hline Crude ash $\left(\mathrm{g} \mathrm{kg}^{-1}\right)$ & 65.0 & 54.0 & 47.0 \\
\hline $\mathrm{Ca}\left(\mathrm{g} \mathrm{kg}^{-1}\right)$ & 12.8 & 11.5 & 7.10 \\
\hline $\mathrm{P}\left(\mathrm{g} \mathrm{kg}^{-1}\right)$ & 8.70 & 7.90 & 5.20 \\
\hline $\mathrm{Zn}\left(\mathrm{mg} \mathrm{kg}^{-1}\right)$ & 172 & 140 & 148 \\
\hline $\mathrm{Fe}\left(\mathrm{mg} \mathrm{kg}^{-1}\right)$ & 258 & 229 & 221 \\
\hline \multicolumn{4}{|c|}{$\mathrm{Cu}$ content of experimental diets ${ }^{*}\left(\mathrm{mg} \mathrm{kg}^{-1}\right)$} \\
\hline $\mathrm{Cu}-\mathrm{SUL}_{20}$ & 31.2 & 29.1 & 30.7 \\
\hline $\mathrm{Cu}-\mathrm{NP}_{20}$ & 28.4 & 27.2 & 26.9 \\
\hline $\mathrm{Cu}-\mathrm{SUL}_{10}$ & 21.1 & 17.9 & 18.8 \\
\hline $\mathrm{Cu}-\mathrm{NP}_{10}$ & 20.4 & 18.3 & 17.6 \\
\hline $\mathrm{Cu}-\mathrm{SUL}_{2}$ & 14.9 & 12.6 & 12.9 \\
\hline $\mathrm{Cu}-\mathrm{NP}_{2}$ & 13.7 & 13.4 & 12.5 \\
\hline
\end{tabular}

${ }^{*}$ Diets supplemented per kg with 2, 10 and $20 \mathrm{mg} \mathrm{Cu}$ in the form of copper sulfate $\left(\mathrm{Cu}-\mathrm{SUL}_{2}, \mathrm{Cu}-\mathrm{SUL}_{10}\right.$, $\left.\mathrm{Cu}-\mathrm{SUL}_{20}\right)$ or 2,10 and $20 \mathrm{mg} \mathrm{Cu}$ in the form of nanoparticles $\left(\mathrm{Cu}-\mathrm{NP}_{2}, \mathrm{Cu}-\mathrm{NP}_{10}, \mathrm{Cu}-\mathrm{NP}_{20}\right)$. 
After 6 and 14 weeks of feeding turkeys diets supplemented with various amounts and sources of $\mathrm{Cu}$, none of the experimental factors affected the body weight of the turkeys or the FCR (Table 3).

Table 3. Growth performance of turkeys fed experimental diets

\begin{tabular}{|c|c|c|c|c|c|c|c|c|c|c|}
\hline \multirow{2}{*}{ Parameters } & \multicolumn{3}{|c|}{$\mathrm{Cu}-\mathrm{SUL} *$} & \multicolumn{3}{|c|}{$\mathrm{Cu}-\mathrm{NP} *$} & \multirow{2}{*}{ SEM } & \multicolumn{3}{|c|}{ P-value } \\
\hline & 20 & 10 & 2 & 20 & 10 & 2 & & Level (L) & Source (S) & $\mathrm{L} \times \mathrm{S}$ interaction \\
\hline \multicolumn{11}{|l|}{ Body weight } \\
\hline day 42 & 2.74 & 2.69 & 2.75 & 2.79 & 2.73 & 2.76 & 0.014 & 0.246 & 0.228 & 0.783 \\
\hline day 102 & 9.55 & 9.51 & 9.43 & 9.55 & 9.46 & 9.56 & 0.043 & 0.828 & 0.733 & 0.741 \\
\hline \multicolumn{11}{|l|}{ FCR $(\mathrm{kg} / \mathrm{kg})$} \\
\hline days $1-42$ & 1.52 & 1.56 & 1.55 & 1.52 & 1.54 & 1.55 & 0.006 & 0.149 & 0.477 & 0.609 \\
\hline days $1-102$ & 2.18 & 2.24 & 2.25 & 2.21 & 2.19 & 2.17 & 0.009 & 0.529 & 0.074 & 0.052 \\
\hline
\end{tabular}

${ }^{*}$ Diets supplemented with 2, 10 and $20 \mathrm{mg}$ of $\mathrm{Cu}$ in the form of copper sulfate (Cu-SUL) or 2, 10 and $20 \mathrm{mg}$ of $\mathrm{Cu}$ in the form of nanoparticles $(\mathrm{Cu}-\mathrm{NP})$

$\mathrm{SEM}=$ standard error of the mean (SD for all birds divided by the square root of the number of birds, $\mathrm{n}=$ 36); FCR, feed conversion ratio.

\section{Antioxidant status of the small intestine}

A statistical analysis of the test results revealed that the dietary addition of $\mathrm{Cu}-$ NPs caused a significant increase in SOD activity $(\mathrm{P}=0.001)$ in the small intestinal tissue compared with that of the Cu-SUL treatment (Table 4). In the Cu-SUL treatment, a degree of source interaction was noted: CAT activity in the small intestinal tissue was lowest in turkeys fed diets supplemented with $20 \mathrm{mg} \mathrm{kg}^{-1} \mathrm{Cu}$, and it significantly increased when doses of 10 and $2 \mathrm{mg} \mathrm{kg}^{-1}$ were applied $(\mathrm{P}=0.001)$. In the $\mathrm{Cu}-$ $\mathrm{NP}$ treatment, the lowest CAT activity was observed in the $\mathrm{Cu}-\mathrm{NP}_{10}$ group $(\mathrm{P}<0.05$ vs. $\mathrm{Cu}-\mathrm{NP}_{2}$ ). A degree of source interaction was also noted for the total glutathione (GSH+GSSG) concentration in the small intestinal tissue, which was highest in the $\mathrm{Cu}-\mathrm{NP}_{10}$ group $(\mathrm{P}<0.05$ vs. all other groups). Irrespective of the $\mathrm{Cu}$ source, the highest and lowest MDA concentrations in the small intestinal tissue were observed when turkey diets were supplemented with $\mathrm{Cu}$ at 20 and $2 \mathrm{mg} \mathrm{kg}^{-1}$, respectively $(\mathrm{P}<0.05)$.

In the bursa of Fabricius, a significant degree of source interaction was noted for the SOD and CAT activities $(\mathrm{P}<0.05)$ (Table 5). In both cases, only the medium dose $\left(10 \mathrm{mg} \mathrm{kg}^{-1}\right)$ of $\mathrm{Cu}-\mathrm{NPs}$ decreased the SOD and CAT activities compared with those of the $\mathrm{Cu}-\mathrm{SUL}_{10}$ group. In the Cu-SUL treatment, the SOD activity in the bursa of Fabricius was significantly reduced in turkeys fed diets supplemented with $2 \mathrm{mg} \mathrm{kg}^{-1}$ $\mathrm{Cu}$ compared with that of groups $\mathrm{Cu}-\mathrm{SUL}_{20}$ and $\mathrm{CU}-\mathrm{SUL}_{10}$. With $\mathrm{Cu}-\mathrm{NP}$ treatment, a decrease in SOD activity was noted when diets were supplemented with 10 and $2 \mathrm{mg} \mathrm{kg}^{-1} \mathrm{Cu}$ vs. that observed in the $\mathrm{Cu}-\mathrm{NP}_{20}$ group. A degree of source interaction was observed for the CAT activity in the bursa of Fabricius, which was significantly lower at a $\mathrm{Cu}$ dose of $10 \mathrm{mg} \mathrm{kg}^{-1}$, but not at 20 and $2 \mathrm{mg} \mathrm{kg}^{-1}$, vs. that observed for the $\mathrm{Cu}-\mathrm{SUL}$ treatment. Irrespective of the $\mathrm{Cu}$ source, the dietary $\mathrm{Cu}$ level of $2 \mathrm{mg} \mathrm{kg} \mathrm{g}^{-1}$ was associated with the lowest concentrations of GSH+GSSG and vitamin $\mathrm{C}$ in the bursa of Fabricius ( $\mathrm{P}<0.05$ vs. 20 and $\left.10 \mathrm{mg} \mathrm{kg}^{-1}\right)$. The highest dietary addition of $\mathrm{Cu}$ resulted in the lowest GSH+GSSG concentration in the bursa of Fabricius $(\mathrm{P}<0.05$ 
vs. 20 and $10 \mathrm{mg} \mathrm{kg}^{-1}$ ). A Cu dose of $2 \mathrm{mg} \mathrm{kg}^{-1}$ contributed to a significant decrease in the MDA concentration in the bursa of Fabricius ( $\mathrm{P}<0.05$ vs. 20 and $10 \mathrm{mg} \mathrm{kg}^{-1}$ ). Regardless of the $\mathrm{Cu}$ level, the dietary application of $\mathrm{Cu}-\mathrm{NPs}$ caused a significant decrease in the total glutathione concentration in this sac-like lymphatic organ in comparison with that of the Cu-SUL treatments.

Table 4. Activity of superoxide dismutase (SOD) and catalase (CAT) and the contents of vitamin C (VIT C), total glutathione (GSH+GSSG), and malondialdehyde (MDA) in the small intestinal wall

\begin{tabular}{|c|c|c|c|c|c|c|c|c|c|c|}
\hline \multirow[b]{2}{*}{ Parameters } & \multicolumn{3}{|c|}{$\mathrm{Cu}-\mathrm{SUL}^{*}$} & \multicolumn{3}{|c|}{$\mathrm{Cu}-\mathrm{NP} *$} & \multirow[b]{2}{*}{ SEM } & \multicolumn{3}{|c|}{$\mathrm{P}$-value } \\
\hline & 20 & 10 & 2 & 20 & 10 & 2 & & \begin{tabular}{|c|} 
Level \\
(L)
\end{tabular} & \begin{tabular}{|c|}
$\begin{array}{c}\text { Source } \\
(\mathrm{S})\end{array}$ \\
\end{tabular} & $\begin{array}{c}\mathrm{L} \times \mathrm{S} \\
\text { interaction }\end{array}$ \\
\hline $\begin{array}{l}\text { SOD } \\
\left(\mathrm{U} \mathrm{g}^{-1} \text { protein }\right)\end{array}$ & 3.37 & 4.16 & 3.88 & 4.10 & 3.73 & 3.87 & 0.082 & 0.511 & 0.001 & 0.273 \\
\hline $\begin{array}{l}\text { CAT } \\
\left(\mathrm{U} \mathrm{g}^{-1} \text { protein }\right)\end{array}$ & $55.2 \mathrm{c}$ & $68.4 \mathrm{a}$ & $64.7 \mathrm{ab}$ & $65.6 \mathrm{ab}$ & $58.1 \mathrm{bc}$ & $71.5 \mathrm{a}$ & 1.319 & 0.020 & 0.299 & 0.001 \\
\hline $\begin{array}{l}\mathrm{GSH}+\mathrm{GSSG} \\
\left(\mu \mathrm{mol} \mathrm{kg}{ }^{-1}\right)\end{array}$ & $2.53 \mathrm{~b}$ & $2.05 \mathrm{~b}$ & $1.99 \mathrm{~b}$ & $2.24 \mathrm{~b}$ & $3.21 \mathrm{a}$ & $2.03 \mathrm{~b}$ & 0.107 & - & - & 0.007 \\
\hline $\begin{array}{l}\text { VIT C } \\
\left(\mu \mathrm{mol} \mathrm{kg}{ }^{-1}\right)\end{array}$ & 154 & 160 & 165 & 150 & 158 & 179 & 3.583 & 0.074 & 0.701 & 0.543 \\
\hline $\begin{array}{l}\text { MDA } \\
\left(\mu \mathrm{mol} \mathrm{kg}{ }^{-1}\right)\end{array}$ & 5.78 & 5.78 & 4.88 & 5.93 & 4.68 & 4.45 & 0.148 & 0.002 & 0.077 & 0.145 \\
\hline
\end{tabular}

${ }^{*}$ Diets supplemented with 2, 10 and $20 \mathrm{mg}$ of $\mathrm{Cu}$ in the form of copper sulfate (Cu-SUL) or 2, 10 and $20 \mathrm{mg}$ of $\mathrm{Cu}$ in the form of nanoparticles (Cu-NP).

$\mathrm{SEM}=$ standard error of the mean (SD for all birds divided by the square root of the number of birds, $\mathrm{n}=36$ ); SOD, superoxide dismutase; CAT, catalase; GSH+GSSG, total glutathione; VIT C, vitamin C; MDA, malondialdehyde.

a, b, c - two-way ANOVA applied; among groups, means within the same line with no common letter differed significantly $(\mathrm{P} \leq 0.05)$ in Duncan's comparison test (calculated only if the $\mathrm{L} \times \mathrm{S}$ interaction was significant).

Table 5. Redox status parameters in the bursa of Fabricius of turkeys

\begin{tabular}{|c|c|c|c|c|c|c|c|c|c|c|}
\hline \multirow[b]{2}{*}{ Parameters } & \multicolumn{3}{|c|}{ Cu-SUL* } & \multicolumn{3}{|c|}{ Cu-NP* } & \multirow[b]{2}{*}{ SEM } & \multicolumn{3}{|c|}{ P-value } \\
\hline & 20 & 10 & 2 & 20 & 10 & 2 & & \begin{tabular}{|c|} 
Level \\
(L)
\end{tabular} & $\begin{array}{c}\text { Source } \\
(\mathrm{S})\end{array}$ & $\begin{array}{c}\mathrm{L} \times \mathrm{S} \\
\text { interaction }\end{array}$ \\
\hline $\begin{array}{l}\text { SOD } \\
\left(\mathrm{U} \mathrm{g}^{-1} \text { protein }\right)\end{array}$ & $9.67 \mathrm{a}$ & $9.85 \mathrm{a}$ & a $8.02 \mathrm{bc}$ & $8.94 \mathrm{ab}$ & $7.26 \mathrm{c}$ & $7.17 \mathrm{c}$ & 0.210 & - & - & 0.023 \\
\hline $\begin{array}{l}\text { CAT } \\
\left(\mathrm{U} \mathrm{g}^{-1} \text { protein }\right)\end{array}$ & $86.6 \mathrm{ab}$ & $89.7 \mathrm{a}$ & $77.4 \mathrm{~b}$ & $84.3 \mathrm{ab}$ & $65.5 \mathrm{c}$ & $77.6 \mathrm{~b}$ & 1.683 & - & - & 0.001 \\
\hline $\begin{array}{l}\mathrm{GSH}+\mathrm{GSSG} \\
(\mu \mathrm{mol} \mathrm{kg-1)}\end{array}$ & 6.78 & 8.01 & 11.2 & 5.19 & 7.41 & 9.67 & 0.345 & $<0.001$ & 0.005 & 0.548 \\
\hline $\begin{array}{l}\text { VIT C } \\
\left.(\mu \mathrm{mol} \mathrm{kg})^{-1}\right)\end{array}$ & 244 & 242 & 254 & 240 & 252 & 255 & 2.026 & 0.048 & 0.523 & 0.386 \\
\hline $\begin{array}{l}\mathrm{LOOH} \\
\left(\mu \mathrm{mol} \mathrm{kg}{ }^{-1}\right)\end{array}$ & 2.72 & 3.30 & 2.82 & 2.71 & 2.90 & 3.08 & 0.106 & 0.418 & 0.746 & 0.466 \\
\hline $\begin{array}{l}\text { MDA } \\
\left.(\mu \mathrm{mol} \mathrm{kg})^{-1}\right)\end{array}$ & 2.72 & 2.86 & 1.85 & 2.61 & 2.67 & 1.68 & 0.128 & 0.001 & 0.511 & 0.988 \\
\hline
\end{tabular}

*Diets supplemented with 2, 10 and $20 \mathrm{mg}$ of $\mathrm{Cu}$ in the form of copper sulfate (Cu-SUL) or 2, 10 and $20 \mathrm{mg}$ of $\mathrm{Cu}$ in the form of nanoparticles $(\mathrm{Cu}-\mathrm{NP})$.

SEM = standard error of the mean (SD for all birds divided by the square root of the number of birds, $n=36$ ); SOD, superoxide dismutase; CAT, catalase; GSH+GSSG, total glutathione; LOOH, hydroperoxides; MDA, malondialdehyde.

a, b, c - two-way ANOVA applied; among groups, means within the same line with no common letter differed significantly $(\mathrm{P} \leq 0.05)$ in Duncan's comparison test (calculated only if the $\mathrm{L} \times \mathrm{S}$ interaction was significant). 


\section{Morphometric parameters}

In the duodenum, the shortest villi and the lowest mucosa thickness were associated with the diet containing $2 \mathrm{mg} \mathrm{kg}^{-1}$ supplemental $\mathrm{Cu}\left(\mathrm{P}<0.05\right.$ vs. the $10 \mathrm{mg} \mathrm{kg}^{-1}$ treatment) (Table 6). An interaction $(\mathrm{P}=0.048)$ between the dietary level and source of $\mathrm{Cu}$ was found for the thickness of the tunica muscularis in the duodenum: higher thicknesses were noted in the $\mathrm{Cu} \mathrm{NP}{ }_{10}$ and $\mathrm{Cu}-\mathrm{SUL}_{2}$ treatments compared with those of the remaining treatments. In the proximal jejunum, the following degree of source interaction was observed: the thickness of tunica muscularis was highest when turkeys were fed a diet with $10 \mathrm{mg} \mathrm{kg}^{-1} \mathrm{Cu}-\mathrm{NPs}$ ( $\mathrm{P}<0.05$ vs. all other groups; Table 7). In the distal jejunum, the following degree of source interaction was noted: the application of Cu-NPs at the lowest level significantly decreased crypt depth when compared with that of the $\mathrm{Cu}-\mathrm{NP}_{10}$ group; such a difference was not observed upon the addition of $\mathrm{Cu}-\mathrm{SUL}$. Irrespective of $\mathrm{Cu}$ level, $\mathrm{Cu}-\mathrm{NPs}$ increased the thickness of tunica muscularis in the distal jejunum compared with that observed with $\mathrm{Cu}-\mathrm{SUL}$ treatment.

Table 6. Depth of the crypts of Lieberkühn, the villus height, thickness of the mucosa (mucosa) and thickness of the tunica muscularis (muscle) in the duodenum of turkeys $(\mu \mathrm{m})$

\begin{tabular}{|c|c|c|c|c|c|c|c|c|c|c|}
\hline \multirow[b]{2}{*}{ Parameters } & \multicolumn{3}{|c|}{$\mathrm{Cu}-\mathrm{SUL}^{*}$} & \multicolumn{3}{|c|}{$\mathrm{Cu}-\mathrm{NP} *$} & \multirow[b]{2}{*}{ SEM } & \multicolumn{3}{|c|}{ P-value } \\
\hline & 20 & 10 & 2 & 20 & 10 & 2 & & $\begin{array}{c}\text { Level } \\
\text { (L) }\end{array}$ & \begin{tabular}{|c|} 
Source \\
$(\mathrm{S})$
\end{tabular} & $\begin{array}{c}\mathrm{L} \times \mathrm{S} \\
\text { interaction }\end{array}$ \\
\hline Villus height & 2478 & 2679 & 2395 & 2421 & 2477 & 2370 & 31.793 & 0.033 & 0.120 & 0.442 \\
\hline Crypt depth & 119 & 132 & 135 & 116 & 127 & 115 & 2.782 & 0.208 & 0.097 & 0.375 \\
\hline Mucosa & 2610 & 2825 & 2545 & 2517 & 2619 & 2501 & 35.21 & 0.045 & 0.093 & 0.599 \\
\hline Muscle & $369 \mathrm{c}$ & $410 \mathrm{bc}$ & $466 \mathrm{a}$ & $364 \mathrm{c}$ & $436 \mathrm{ab}$ & $406 \mathrm{bc}$ & 8.367 & - & - & 0.048 \\
\hline
\end{tabular}

*Diets supplemented with 2, 10 and $20 \mathrm{mg}$ of $\mathrm{Cu}$ in the form of copper sulfate (Cu-SUL) or 2, 10 and $20 \mathrm{mg}$ of $\mathrm{Cu}$ in the form of nanoparticles (Cu-NP).

$\mathrm{SEM}=$ standard error of the mean (SD for all birds divided by the square root of the number of birds, $\mathrm{n}=36$ ).

a, b, c - two-way ANOVA applied; among groups, means within the same line with no common letter differed significantly $(\mathrm{P} \leq 0.05)$ in Duncan's comparison test (calculated only if the $\mathrm{L} \times \mathrm{S}$ interaction was significant).

Table 7. Depth of the crypts of Lieberkühn, the height of villi, thickness of the mucosa (mucosa) and thickness of the tunica muscularis (muscle) in the jejunum of turkeys fed experimental diets $(\mu \mathrm{m})$

\begin{tabular}{|c|c|c|c|c|c|c|c|c|c|c|}
\hline \multirow[b]{2}{*}{ Parameters } & \multicolumn{3}{|c|}{ Cu-SUL* } & \multicolumn{3}{|c|}{$\mathrm{Cu}-\mathrm{NP} *$} & \multirow[b]{2}{*}{ SEM } & \multicolumn{3}{|c|}{$\mathrm{P}$-value } \\
\hline & 20 & 10 & 2 & 20 & 10 & 2 & & $\begin{array}{l}\text { Level } \\
\text { (L) }\end{array}$ & $\begin{array}{c}\text { Source } \\
\text { (S) }\end{array}$ & $\begin{array}{c}\mathrm{L} \times \mathrm{S} \\
\text { interaction }\end{array}$ \\
\hline 1 & 2 & 3 & 4 & 5 & 6 & 7 & 8 & 9 & 10 & 11 \\
\hline
\end{tabular}

Proximal

jejunum

\begin{tabular}{lcccccccccc} 
villus height & 2612 & 2382 & 2285 & 2502 & 2350 & 2441 & 40.77 & 0.087 & 0.955 & 0.388 \\
crypt depth & 125 & 136 & 123 & 124 & 121 & 124 & 2.01 & 0.625 & 0.232 & 0.235 \\
mucosa & 2748 & 2520 & 2425 & 2635 & 2603 & 2574 & 37.12 & 0.100 & 0.584 & 0.317 \\
muscle & $481 \mathrm{~b}$ & $438 \mathrm{~b}$ & $466 \mathrm{~b}$ & $439 \mathrm{~b}$ & $559 \mathrm{a}$ & $411 \mathrm{~b}$ & 11.63 & - & - & 0.001 \\
\hline
\end{tabular}


Table 7 - contd.

\begin{tabular}{l|c|c|c|c|c|c|c|c|c|c}
\hline \multicolumn{1}{c}{1} & 2 & 3 & 4 & 5 & 6 & 7 & 8 & 9 & 10 & 11 \\
\hline $\begin{array}{l}\text { Middle jejunum } \\
\text { villus height }\end{array}$ & 1550 & 1649 & 1597 & 1557 & 1668 & 1658 & 26.32 & 0.269 & 0.595 & 0.908 \\
crypt depth & 146 & 126 & 142 & 141 & 132 & 132 & 3.29 & 0.230 & 0.671 & 0.645 \\
mucosa & 1706 & 1794 & 1749 & 1702 & 1804 & 1805 & 26.92 & 0.350 & 0.712 & 0.902 \\
muscle & 396 & 368 & 434 & 406 & 390 & 413 & 7.50 & 0.055 & 0.817 & 0.468 \\
Distal jejunum & & & & & & & & & & \\
villus height & 1501 & 1567 & 1494 & 1436 & 1478 & 1523 & 25.53 & 0.687 & 0.435 & 0.632 \\
crypt depth & $125 \mathrm{ab}$ & $134 \mathrm{a}$ & $114 \mathrm{~b}$ & $114 \mathrm{~b}$ & $126 \mathrm{ab}$ & 126 ab & 2.014 & - & - & 0.029 \\
mucosa & 1649 & 1704 & 1612 & 1553 & 1596 & 1674 & 26.30 & 0.725 & 0.383 & 0.357 \\
muscle & 437 & 410 & 456 & 513 & 468 & 445 & 8.87 & 0.189 & 0.014 & 0.074 \\
\hline
\end{tabular}

${ }^{*}$ Diets supplemented with 2, 10 and $20 \mathrm{mg}$ of $\mathrm{Cu}$ in the form of copper sulfate (Cu-SUL) or 2, 10 and $20 \mathrm{mg}$ of $\mathrm{Cu}$ in the form of nanoparticles (Cu-NP).

$\mathrm{SEM}=$ standard error of the mean (SD for all birds divided by the square root of the number of birds, $\mathrm{n}=36$ ).

a, b - two-way ANOVA applied; among groups, means within the same line with no common letter differed significantly $(\mathrm{P} \leq 0.05)$ in Duncan's comparison test (calculated only if the $\mathrm{L} \times \mathrm{S}$ interaction was significant).

\section{Mineral digestibility}

Regardless of the $\mathrm{Cu}$ source, the lowest inclusion level of supplemental $\mathrm{Cu}$ resulted in a significant increase in the apparent digestibility coefficient of $\mathrm{Fe}(\mathrm{P}<0.05$ vs. 10 and $20 \mathrm{mg} \mathrm{kg}^{-1}$; Table 8). Dietary supplementation with $10 \mathrm{mg} \mathrm{kg}^{-1} \mathrm{Cu}$ led to a significant decrease in the apparent digestibility coefficient of $\mathrm{P}$ compared with that of the $20 \mathrm{mg} \mathrm{kg}^{-1}$ treatment. Irrespective of the $\mathrm{Cu}$ level, the dietary application of $\mathrm{Cu}-\mathrm{NPs}$ caused a significant decrease in the apparent digestibility coefficient of $\mathrm{Fe}(\mathrm{P}<0.05$ vs. the $\mathrm{Cu}-\mathrm{SUL}$ treatment). Significant levels of source interactions were noted for the apparent digestibility coefficients of $\mathrm{Cu}$ and $\mathrm{Zn}$. When $\mathrm{Cu}-\mathrm{NPs}$ were applied instead of Cu-SUL at 10 and $2 \mathrm{mg} \mathrm{kg}^{-1}$ (but not at $20 \mathrm{mg} \mathrm{kg}^{-1}$ ), the apparent digestibility coefficient of $\mathrm{Cu}$ was significantly higher. The highest apparent digestibility coefficient of $\mathrm{Cu}$ was noted in the $\mathrm{Cu}-\mathrm{NP}_{2}$ group ( $\mathrm{P}<0.05$ vs. all other groups). Similarly, the $\mathrm{Cu}-\mathrm{NP}_{2}$ group was characterized by the highest apparent digestibility coefficient of $\mathrm{Zn}(\mathrm{P}<0.05$ vs. all other groups).

Table 8. Apparent digestibility coefficients of minerals (\%)

\begin{tabular}{|c|c|c|c|c|c|c|c|c|c|c|}
\hline \multirow[b]{2}{*}{ Parameters } & \multicolumn{3}{|c|}{ Cu-SUL* } & \multicolumn{3}{|c|}{ Cu-NP* } & \multirow[b]{2}{*}{ SEM } & \multicolumn{3}{|c|}{$\mathrm{P}$-value } \\
\hline & 20 & 10 & 2 & 20 & 10 & 2 & & \begin{tabular}{|c} 
Level \\
(L)
\end{tabular} & $\begin{array}{l}\text { Source } \\
\text { (S) }\end{array}$ & $\begin{array}{c}\mathrm{L} \times \mathrm{S} \\
\text { interaction }\end{array}$ \\
\hline$\overline{\mathrm{Cu}}$ & $23.2 \mathrm{~d}$ & $27.5 \mathrm{c}$ & $36.2 \mathrm{~b}$ & $26.2 \mathrm{~cd}$ & $38.3 \mathrm{~b}$ & $56.3 \mathrm{a}$ & 1.704 & - & - & $<0.001$ \\
\hline $\mathrm{Zn}$ & $25.4 \mathrm{~b}$ & $29.8 \mathrm{~b}$ & $24.5 \mathrm{~b}$ & $28.4 \mathrm{~b}$ & $25.7 \mathrm{~b}$ & $47.6 \mathrm{a}$ & 1.383 & - & - & $<0.001$ \\
\hline $\mathrm{Fe}$ & 16.3 & 18.5 & 23.5 & 11.6 & 13.7 & 17.7 & 0.831 & $<0.001$ & $<0.001$ & 0.926 \\
\hline$P$ & 67.4 & 59.3 & 66.6 & 68.4 & 63.3 & 61.4 & 0.924 & 0.009 & 0.960 & 0.083 \\
\hline $\mathrm{Ca}$ & 56.5 & 51.3 & 55.8 & 50.9 & 52.1 & 53.8 & 0.786 & 0.252 & 0.149 & 0.232 \\
\hline
\end{tabular}

${ }^{*}$ Diets supplemented with 2, 10 and $20 \mathrm{mg}$ of $\mathrm{Cu}$ in the form of copper sulfate (Cu-SUL) or 2, 10 and $20 \mathrm{mg}$ of $\mathrm{Cu}$ in the form of nanoparticles $(\mathrm{Cu}-\mathrm{NP})$.

$\mathrm{SEM}=$ standard error of the mean (SD for all birds divided by the square root of the number of birds, $\mathrm{n}=36$ ).

a, b, c, d-two-way ANOVA applied; among groups, means within the same line with no common letter differed significantly $(\mathrm{P} \leq 0.05)$ in Duncan's comparison test (calculated only if the $\mathrm{L} \times \mathrm{S}$ interaction was significant). 


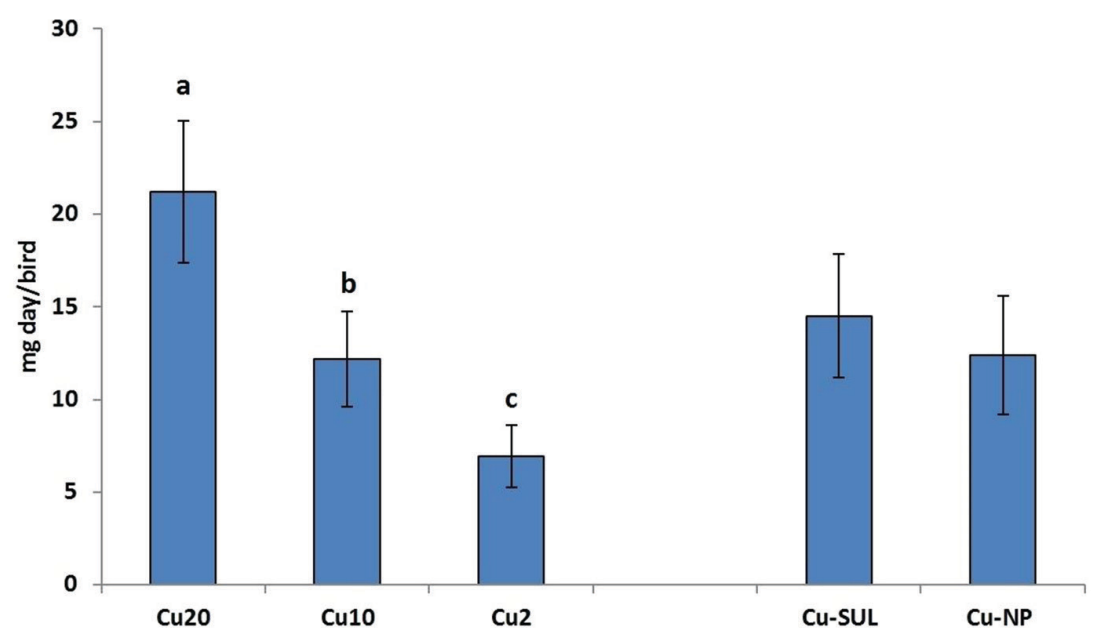

a, b, $\mathrm{c}-$ bars with different letters differ significantly $(\mathrm{P} \leq 0.05)$ in Duncan's comparison test.

Figure 1. Calculated amount of undigested copper excretion (mg/day/bird) in turkeys fed diets with different inclusion levels ( $\mathrm{mg} \mathrm{kg} \mathrm{kg}^{-1}$ feed; treatments denoted as $\mathrm{Cu}_{20}, \mathrm{Cu}_{10}, \mathrm{Cu}_{2}$ ) of $\mathrm{Cu}-\mathrm{SUL}$ (copper sulfate) and $\mathrm{Cu}-\mathrm{NP}$ (copper nanoparticles)

Regardless of the $\mathrm{Cu}$ source, the amount of undigested $\mathrm{Cu}$ excreted into the environment decreased from $21.2 \mathrm{mg} \mathrm{day}^{-1}$ bird $^{-1}$ in the $\mathrm{Cu}_{20}$ group to 12.2 and $6.95 \mathrm{mg}$ day ${ }^{-1}$ bird ${ }^{-1}$ in the $\mathrm{Cu}_{10}$ and $\mathrm{Cu}_{2}$ groups, respectively (Figure 1). The replacement of $\mathrm{Cu}-\mathrm{SUL}$ with $\mathrm{Cu}-\mathrm{NPs}$ only slightly decreased the amount of undigested $\mathrm{Cu}$ (from 14.5 to $12.4 \mathrm{mg} \mathrm{day}^{-1}$ bird $^{-1}$ ).

\section{Discussion}

\section{Dietary $\mathrm{Cu}$ content and growth performance}

In the first stage of the present experiment (days 1-42), the total $\mathrm{Cu}$ content in the three dietary treatments $\left(2,10\right.$, and $\left.20 \mathrm{mg} \mathrm{kg}^{-1}\right)$ was lower, similar to and higher, respectively, than the recommended level for poultry diets in the EU, i.e., $25 \mathrm{mg}$ $\mathrm{kg}^{-1}$ (EFSA, 2016). In the subsequent stages of the study, the total $\mathrm{Cu}$ content of the turkey diets was 1 to 2 percentage units lower than the EU-recommended level, most likely due to the lower $\mathrm{Cu}$ content of the feed ingredients and an increase in the ground wheat content at the expense of soybean meal. This was consistent with the results of other studies in which basal diets with known $\mathrm{Cu}$ contents were supplemented with different amounts of $\mathrm{Cu}$ (Mabe et al., 2003; Arias and Koutsos, 2006). According to the literature, supplemental $\mathrm{Cu}$ may promote growth in chickens at very high doses, i.e., those reaching 100-450 mg kg-1 (Pekel and Alp, 2011; Samanta et al., 2011). Makarski et al. (2014) observed no improvement in the growth rate of turkeys at lower dietary $\mathrm{Cu}$ levels (15 and $65 \mathrm{mg} \mathrm{Cu} \mathrm{kg}^{-1}$ ). Similar results were noted 
in our study, where dietary supplementation with $\mathrm{Cu}-\mathrm{SUL}$ or $\mathrm{Cu}-\mathrm{NPs}$ had no influence on the growth performance of female turkeys.

\section{Antioxidant status of the small intestine}

Research has shown that cellular susceptibility to oxidative damage can be due to both the excess (Ajuwon et al., 2011) and deficiency of dietary $\mathrm{Cu}$ (O'Connor, 2001). Dietary $\mathrm{Cu}$ is an important part of the body's antioxidant system, and a $\mathrm{Cu}$ deficiency reduces the activity of $\mathrm{Cu}$-containing enzymes, including $\mathrm{Cu}, \mathrm{Zn}-\mathrm{SOD}$ and ceruloplasmin (Sukalski et al., 1997). Recent data, presented as another part of the present study, showed that the $20 \mathrm{mg} \mathrm{kg}^{-1} \mathrm{Cu}-\mathrm{NP}$ treatment, but not the lower doses, negatively affected the redox status of blood and stimulated the synthesis of the proinflammatory cytokine IL-6 (Jankowski et al., 2019). In the present experiment, the dietary $\mathrm{Cu}$ inclusion levels of 20 and $10 \mathrm{mg} \mathrm{kg}^{-1}$ had no influence on the analysed parameters of the redox status of the small intestinal wall. Interestingly, diets with the lowest level of $\mathrm{Cu}$ supplementation $\left(2 \mathrm{mg} \mathrm{kg}^{-1}\right)$ caused a decrease in the concentrations of oxidation products, as measured by the MDA level. It can be assumed that the antioxidant balance status of blood, compared with that of internal tissues, seems to be more prone to undesirable changes upon unbalanced (excess or deficiency) dietary $\mathrm{Cu}$ levels. Regarding the $\mathrm{Cu}$ source, the replacement of $\mathrm{Cu}-$ SUL with Cu-NPs increased the SOD activity and tended to decrease MDA levels in the small intestinal wall. The medium dose of supplemental $\mathrm{Cu}-\mathrm{NPs}$ increased the concentrations of GSH+GSSG but decreased the CAT activity in the small intestinal wall. The above results indicate slight modulatory effects exerted by $\mathrm{Cu}-\mathrm{NPs}$ on the intestinal redox status, which should be thoroughly examined.

It has been reported that high amounts of supplemental $\mathrm{Cu}$ (above $300 \mathrm{mg} \mathrm{kg}^{-1}$ ) decrease the weight and growth index of the bursa of Fabricius, the primary lymphoid organ in avian species (Yang et al., 2009). The effect of lower dietary $\mathrm{Cu}$ levels on the size and function of the bursa of Fabricius has not been investigated to date. In the current study, the lowest $\mathrm{Cu}$ dietary treatments were found to reduce MDA levels in the bursa of Fabricius. The desirable reduction in MDA concentration may be attributed to higher levels of glutathione and vitamin $\mathrm{C}$ in the bursa of Fabricius.

\section{Morphometric parameters}

Research has shown that dietary $\mathrm{Cu}$ supplementation may affect mucosal histology via alterations of the gut microbiota (Johnson et al., 1985; Awad et al., 2009). In a broiler chicken trial, a dose above $250 \mathrm{mg} \mathrm{Cu}$ per $\mathrm{kg}$ of feed significantly reduced the villus height and significantly thickened the muscular layer in the duodenum (Chiou et al., 1999). The increased surface area of nanoparticles supports their adhesion to the substrate, deeper penetration into tissues through fine capillaries and prolonged residence of the compounds in the intestines (Chen et al., 2006). It appears that higher dietary levels of $\mathrm{Cu}-\mathrm{NPs}$ could induce changes in the intestinal epithelium, and there are no published studies involving lower dietary inclusion levels. In the present experiment, certain intestinal morphometric changes were noted, but they did not follow a clear trend depending on the dietary level and source of $\mathrm{Cu}$. 


\section{Mineral digestibility}

It has been found that changes in essential trace mineral digestibility in the gastrointestinal tract are primary mechanisms for maintaining trace mineral homeostasis (King et al., 2000). In the current study, a decrease in the dietary inclusion levels of $\mathrm{Cu}$ from 20 to 10 and then to $2 \mathrm{mg} \mathrm{kg}^{-1}$ led to a natural increase in the apparent $\mathrm{Cu}$ digestibility coefficient. Only in the case of $\mathrm{Zn}$ was the highest coefficient of intestinal digestibility observed in the $\mathrm{Cu}-\mathrm{NP}_{2}$ treatment, where $\mathrm{Cu}$ digestibility was highest. This indicates that the smallest dose of $\mathrm{Cu}$, including the more readily absorbed form, $\mathrm{Cu}-\mathrm{NPs}$, decreased $\mathrm{Cu}$ and $\mathrm{Zn}$ antagonism in gastrointestinal absorption, as noted in other experiments (Adegbenjo et al., 2014; Ognik et al., 2016). In the case of $\mathrm{Fe}$, digestibility coefficients were higher at the lowest dietary addition of $\mathrm{Cu}$, which corroborates the findings of other authors (Linder and Hazegh-Azam, 1996; Schoendorfer and Davies, 2012), indicating that $\mathrm{Cu}$ and Fe compete for transport and bioavailability.

The replacement of $\mathrm{Cu}-\mathrm{SUL}$ with $\mathrm{Cu}-\mathrm{NPs}$ increased the apparent digestibility coefficient of $\mathrm{Cu}$ in turkeys fed diets with the medium and lowest $\mathrm{Cu}$ doses. This finding confirms the opinion that, due to their small size, nanoparticles penetrate more easily through fine capillaries in the intestines (Chen et al., 2006). In our experiment, $\mathrm{Cu}-\mathrm{NPs}$ increased $\mathrm{Zn}$ digestibility (but only when the lowest dietary $\mathrm{Cu}$ levels were applied) and decreased Fe digestibility. Research has shown that $\mathrm{Cu}$ competes with Fe for intestinal absorption (Linder and Hazegh-Azam, 1996). However, a different relationship has also been reported: $\mathrm{Cu}$ deficiency reduces $\mathrm{Fe}$ absorption, which is linked to intestinal Fe transport being Cu-dependent (Schoendorfer and Davies, 2012). In view of the above findings, increased Fe digestibility in turkeys fed diets with the lowest $\mathrm{Cu}$ dose is indicative of the absence of $\mathrm{Cu}$ deficiency symptoms.

In an experiment on piglets, $\mathrm{Cu}$ availability was significantly improved, and faecal $\mathrm{Cu}$ excretion was reduced in the $\mathrm{Cu}-\mathrm{NP}$ group compared with that of the Cu-SUL group (Gonzales-Eguia et al., 2009). Other authors have also demonstrated that the use of nanoparticles, including $\mathrm{Cu}$ nanoparticles, as feed additives can improve the digestion and absorption of nutrients in livestock (Bunglavan et al., 2014; Gangadoo et al., 2016; Hill and Li, 2017). In our experiment, the replacement of Cu-SUL with $\mathrm{Cu}-\mathrm{NP}$ decreased the amount of undigested $\mathrm{Cu}$ excreted with faeces (from 14.5 to $12.4 \mathrm{mg} \mathrm{kg}^{-1}$ ), thus reducing the environmental burden. However, better results were achieved when the amount of supplemental $\mathrm{Cu}$ was decreased from 20 to 10 and $2 \mathrm{mg} \mathrm{kg}^{-1}$.

\section{Conclusions}

The results of this study indicate that a decrease in the dietary inclusion levels of $\mathrm{Cu}$ from $20 \mathrm{mg} \mathrm{kg}^{-1}$ to 10 and $2 \mathrm{mg} \mathrm{kg}^{-1}$ did not reduce the body weights of turkeys and had no adverse effect on the morphometric parameters of the small intestine. Surprisingly, the lowest amount of additional $\mathrm{Cu}\left(2 \mathrm{mg} \mathrm{kg}^{-1}\right)$ improved the antioxidant status of the small intestinal tissue and the bursa of Fabricius. In comparison with $\mathrm{Cu}-\mathrm{SUL}, \mathrm{Cu}-\mathrm{NPs}$ did not compromise the growth performance of turkeys and improved selected indicators of the redox status in the host tissues (including an increase in SOD activity in the small intestine and glutathione levels in the bursa 
of Fabricius). The lowest amount of additional $\mathrm{Cu}$ in the form of nanoparticles increased the apparent digestibility of $\mathrm{Cu}$ and $\mathrm{Zn}$. Therefore, the environmental burden of excreted $\mathrm{Cu}$ was substantially reduced along with decreasing dietary $\mathrm{Cu}$ levels but to a lesser extent when copper sulfate was replaced with $\mathrm{Cu}$ nanoparticles. In view of the results of the present study, some of which were quite surprising, further debate is needed to establish the dietary requirements for $\mathrm{Cu}$ in turkeys and the efficacy of $\mathrm{Cu}$ nanoparticles in poultry nutrition.

\section{Declarations of interest}

None.

\section{Acknowledgements}

This experiment was conducted under the Biostrateg program "GUTFEED - innovative nutrition in sustainable poultry production” 267659/7/NCBR/2015.

\section{References}

A degbenjo A.A., Idowu O.M.O., O so A.O., A deyemi O.A., A obayo R.A., A kin 1 oy e O.A., J e g e d e A.V., O s ho S.O., Willi a m s G.A. (2014). Effects of dietary supplementation with copper sulphate and copper proteinate on plasma trace minerals, copper residues in meat tissues, organs, excreta and tibia bone of cockerels. Slovak J. Anim. Sci., 47: 164-171.

A e b i H. (1984). Catalase in vitro. Method. Enzymol., 105: 121-126.

Ajuwon O.R., Id owu O.M.O., A folabi S.A., Kehinde B.O., Oguntola O.O., Olatunb o s u n K.O. (2011). The effects of dietary copper supplementation on oxidative and antioxidant systems in broiler chickens. Arch. Zootec., 60: 275-282.

A $1 \mathrm{~b}$ a n e s e A., T a n g P.S., C h a n W.C.W. (2012). The effect of nanoparticle size, shape, and surface chemistry on biological systems. Annu. Rev. Biomed. Eng., 14: 1-16.

A $n$ w a r M.I., Aw a is M.M., A kht a r M., N a vid M.T., M u h a m m a d F. (2019). Nutritional and immunological effects of nano-particles in commercial poultry. World Poult. Sci. J., 75: 262-271.

Aria s V.J., K outs o s E.A. (2006). Effect of copper source and level on intestinal physiology and growth of broiler chickens. Poultry Sci., 85: 999-1007.

Aw ad W.A., Ghare e b K., A bd e l-R a he e m S., B ohm J. (2009). Effects of dietary inclusion of probiotic and synbiotic on growth performance, organ weights, and intestinal histomorphology of broiler chickens. Poultry Sci., 88: 49-55.

B a o Y.M., Choct M., Iji P., Bruerton A. (2007). Effect of organically complexed copper, iron, manganese, and zinc on broiler performance, mineral excretion, and accumulation in tissues. J. Appl. Poultry Res., 16: 448-455.

B ung l a van S.J., D a s s A.K.G., Shrivastav a S. (2014). Use of nanoparticles as feed additives to improve digestion and absorption in livestock. Livest. Res. Int., 2: 36-47.

Che n Z., M eng H., X ing G., Ch en C., Z h a o Y., Ji a G., W ang T., Yu an H., Ye C., Z h a o F., Chai Z., Zhu C., Fang X., Ma B., Wan L. (2006). Acute toxicological effects of copper nanoparticles in vivo. Toxicol. Lett., 163: 109-120.

Ch i o u P.W.S., Ch en C.L., Ch e n K.L., W u C.P. (1999). Effect of high dietary copper on the morphology of gastro-intestinal tract in broiler chickens. Asian Austral. J. Anim. Sci., 12: 548-553.

Cholewińska E., Juśkiewicz J., Ognik K. (2018 a). Comparison of the effect of dietary copper nanoparticles and one copper (II) salt on the metabolic and immune status in a rat model. J. Trace Elem. Med Biol., 48: 111-117.

Cholewińska E., Ognik K., Fots chki B., Z duńczyk Z., Juśki ew i cz J. (2018b). Comparison of the effect of dietary copper nanoparticles and one copper (II) salt on the copper biodistri- 
bution and gastrointestinal and hepatic morphology and function in a rat model. PLoS ONE, 13(5): e0197083.

Crater J.S., Carrier R.L. (2010). Barrier properties of gastrointestinal mucus to nanoparticles transport. Macromol. Biosci., 10: 1473-1483.

EFSA Panel on Additives and Products or Substances used in Animal Feed (FEEDAP) (2016). Revision of the currently authorised maximum copper content in complete feed. EFSA J., 14: 4563.

Gangad o o S., Stan le y D., Hughus R., Mo or e R.J., Chap man J. (2016). Nanoparticles in feed: Progress and prospects in poultry research. Trends Food Sci. Tech., 58: 115-126.

Gonzales-Egui a A., Fu C.M., Lu F.Y., Lien T.F. (2009). Effects of nanocopper on copper availability and nutrients digestibility, growth performance and serum traits of piglets. Livest. Sci., 126: $122-129$.

Hill E.K., Li J. (2017). Current and future prospects for nanotechnology in animal production. J. Anim. Sci. Biotechnol., 8: 26.

H i 11 e r y A.M., J a n i P.U., F 1 o r e n c e A.T. (1994). Comparative, quantitative study of lymphoid and nonlymphoid uptake of $60 \mathrm{~nm}$ polystyrene particles. J. Drug. Target., 2: 151-156.

J a chak A., Lai S.K., Hida K., Suk J.S., Markovic N., B is wal S., Breys se P.N., Ha$\mathrm{n}$ e s J. (2012). Transport of metal oxide nanoparticles and single-walled carbon nanotubes in human mucus. Nanotoxicology, 6: 614-622.

Jani P., Halbert G.W., Langridge J., Florence A.T. (1990). Nanoparticle uptake by the rat gastrointestinal mucosa: quantitation and particle size dependency. J. Pharm. Pharmacol., 42: 821-826.

Jankowski J., Kozłowski K., Ognik K., Zduńczyk Z., Otowski K., Sawosz E., J u ś k i e w i c z J. (2019). Redox and immunological status of turkeys fed diets with different levels and sources of copper. Ann. Anim. Sci., 19: 215-227.

J e g e de A.V., O du g u w a O.O., O s o A.O., F a fi o 1 u A.O., I d o w u O.M.O., N o 11 e t L. (2012). Growth performance, blood characteristics and plasma lipids of growing pullet fed dietary concentrations of organic and inorganic copper sources. Livest. Sci., 145: 298-302.

J o hn s o n E.L., N i c h o l o s o n J.L., D o e r r J.A. (1985). Effect of dietary copper on litter microbial population and broiler performance. Brit. Poult. Sci., 26: 171-177.

Jóźwik A., Marchewka J., Strzałkowska N., Horbńanczuk J.O., Szumacher- Strabel M., Cieślak A., Lipińska-Palka P., Józefiak D., Kamińska A., A t a n a s ov A.G. (2018). The effect of different levels of $\mathrm{Cu}, \mathrm{Zn}$ and $\mathrm{Mn}$ nanoparticles in hen turkey diet on the activity of aminopeptidases. Molecules, 23: 1150.

K a r i m i A., S a d e g h i G., Va z i r y A. (2011). The effect of copper in excess of the requirement during the starter period on subsequent performance of broiler chicks. J. Appl. Poult. Res., 20: 203-209.

K in g J.C., Sha me s D.M., Wo o d h o u s e L.R. (2000). Zinc homeostasis in humans. J. Nutr., 130: 1360S-1366S.

L i m H.S., P a i k I.K. (2006). Effects of dietary supplementation of copper chelates in the form of methionine, chitosan and yeast in laying hens. Asian-Aust. J. Anim. Sci., 19: 1174-1178.

Linder M.C., Hazegh-A zam M. (1996). Copper biochemistry and molecular biology. Am. J. Clin. Nutr., 63: 797-811.

M a b e I., R a p p C., B a in M.M., N y s Y. (2003). Supplementation of a corn-soybean meal diet with manganese, copper, and zinc from organic or inorganic sources improves eggshell quality in aged laying hens. Poultry Sci., 82: 1902-1913.

Majewski M., Ognik K., Zduńczyk P., Juśkiewicz J. (2017). Effect of dietary copper nanoparticles versus one copper (II) salt: analysis of vasoreactivity in a rat model. Pharmacol. Rep., 69: $1282-1268$.

Makarski B., Gortat M., Lechowski J., Żukiewicz-Sobczak W., Sobczak P., Zaw i śl a k K. (2014). Impact of copper $(\mathrm{Cu})$ at the dose of $50 \mathrm{mg}$ on haematological and biochemical blood parameters in turkeys, and level of $\mathrm{Cu}$ accumulation in the selected tissues as a source of information on product safety for consumers. Ann. Agric. Environ. Med., 21: 567-570.

M c Gil1 S., S m y th H.D.C. (2010). Disruption of the mucus barrier by topically applied exogenous particles. Mol. Pharmaceutics, 7: 2280-2288.

O ' C o n n or J.M. (2001). Trace elements and DNA damage. Biochem. Soc. Trans., 39: 354-357.

O g n i k K., We rt e le c k i T. (2012). Effect of different vitamin E sources and levels on selected oxi- 
dative status indices in blood and tissues as well as on rearing performance of slaughter turkey hens. J. Appl. Poultry Res., 2: 259-271.

Ognik K., Stępniowska A., Cholewińska E., Kozłowski K. (2016). The effect of administration of copper nanoparticles to chickens in drinking water on estimated intestinal absorption of iron, zinc, and calcium. Poultry Sci., 95: 2045-2051.

Ognik K., S e mbratowicz I., Cholewińska E., Jankowski J., Kozłowski K., Juśkiewicz J., Zduńczyk Z. (2018). The effect of administration of copper nanoparticles to chickens in their drinking water on the immune and antioxidant status of blood. Anim. Sci. J., 89: 579-588.

Ognik K., Cholewińska E., Juśkiewicz J., Zduńczyk Z., Tutaj K., Szlązak R. (2019 a). The effect of copper nanoparticles and copper (II) salt on redox reactions and epigenetic changes in a rat model. J. Anim. Physiol. Anim. Nutr., 103: 675-686.

O gnik K., Cholewińska E., Stępniowska A., Drażbo A., Kozłowski K., Jankow ski J. (2019 b). The effect of administration of copper nanoparticles in drinking water on redox reactions in the liver and breast muscle of broiler chickens. Ann. Anim. Sci., 19: 663-677.

O maye S.T., Tu mbull J.D., S a uberlich H.E. (1979). Selected methods for determination of ascorbic acid in animal cells, tissues and fluids. Meth. Enzymol., 62: 3-11.

O towski K., Ognik K., Kozłowski K. (2019). Growth rate, metabolic parameters and carcass quality in turkeys fed diets with different inclusion levels and sources of supplemental copper. J. Anim. Feed Sci., 28: 272-281.

P e k e 1 A., A l p M. (2011). Effects of different dietary copper sources on laying hen performance and egg yolk cholesterol. J. Appl. Poult. Res., 20: 506-513.

S a m a n t a B., Ghos h P.R., B i s w as A., D a s S.K. (2011). The effects of copper supplementation on the performance and hematological parameters of broiler chickens. Asian-Aust. J. Anim. Sci., 24: 1001-1006.

S aw os z E., Łukasiew icz M., Łozicki A., S osnowska M., Jaw orski S., Nie mi e c J., S c ot t A., J a nk ow ski J., Józ efi a k D., C hwa libog A. (2018). Effect of copper nanoparticles on the mineral content of tissues and droppings, and growth of chickens. Archiv. Anim. Nutr., 72: 396-406.

S choendorfer N., Davies P.S.W. (2012). Micronutrients interrelationships: synergism and antagonism. In: Micronutrients, Betencourt A.I., Gaitan H.F. (eds). pp. 159-179.

S c ott A., Vadal a set ty K.P., Chw ali bog A., S a w os z E. (2018). Copper nanoparticles as an alternative feed additive in poultry diet: a review. Nanotechnol. Rev., 7: 69-93.

S mulikowska S., Rutk ow ski A. (2005). Recommended allowances and nutritive value of feedstuffs - poultry feeding standards (in Polish). 5th ed. Smulikowska S., Rutkowski A., eds. The Kielanowski Institute of Animal Physiology and Nutrition, Jablonna, PAS Polish.

$\mathrm{S}$ u k a $1 \mathrm{~s}$ k i K.A., L a B e r g e T.P., J o h n s o n W.T. (1997). In vivo oxidative modification of erythrocyte membrane proteins in copper deficiency. Free Radic. Biol. Med., 22: 835-842.

Yang F., Z h a o L., P eng X., D en g J.L., C u i H.M. (2009). Effect of dietary high copper on the bursa of Fabricius in ducklings. Chin. J. Vet. Sci., 29: 354-359.

Received: 27 VIII 2019

Accepted: 9 I 2020 